\title{
発展途上国への技術移転 \\ TECHNOLOGY TRANSFER TO DEVELOPING COUNTRIES
}

竹内 良 太*

By Yoshio TAKEUCHI

\section{1. 発展途上国に対する技術協力}

発展途上国に対して技術を移転すること は, 開発途上にあるこれらの国々の経済 的, 社会的発展を促すための技術分野にお ける支援の一つであり, 先進国側の責務で もある.この意味において, 国際協力, 経 済協力の一形態として, 技術協力と呼ばれ ているともいえよう.

技術協力を論ずる上で重要なことは，技 術を移転する側とこれを受け入れる側との間の “人と人 とのつながり”無くして，この行為が実効あるものとは ならないということである. 経済協力のあり方は広範に わたるが，この点が “整や物”を提供する援助との大き な違いであり,むしろ物質的な観点からでは行い得ない ところに技術協力の特殊性があるように思われる.

経済協力を, そこに投じられる資金の種類により分類 寸れば, ODA (Official Development Assistance) と略称され る政府開発援助, OOF (Other Official Flow) といわれるそ の他政府資金および PF (Private Fund) と呼ばれる民間資 金の三つに区分される.技術協力はこれらのいずれによ っても直接的または間接的に行われているが, ODAに よる研修員の受け入れ, 専門家の派遣, 調査団の派遣, 青年海外協力隊の派遣などがその主流をなしている. 近 年日本が実施している発展途上国に対する経済協力は表 -1 に示すとおりであり, 経済協力における ODA の役

* 正会員 工博 関西国際空港 (株) 社長, (財) 国際臨海開発 研究センター顧問

（干542/大阪市南区南船場 3-11-18, 郵政互助会心晟橋ビル）
割は年々その重要性を増し, 1983 年の援 助額は全体の $43.4 \%$ を占めるところとな った．技術協力に係る援助額も増加が著し く, 発展途上国側からの技術移転に対する 強い期待を窥い知ることができる.

土木の分野に係る技術協力は, 港湾, 道 路, 鉄道といったインフラストラクチャー の整備に必要な技術の移転が根幹的なもの である. いわば国ゔくりの基盤となる施設 の計画, 建設, 維持・管理, 運営のための 技術水準を向上させることに目的がある.

したがって，援助額が増大することは好ましいことであ り重要なことではあるが, むしろ移転される技術の質と 行為を実行する人の善意に焦点が当てられなければなら ない. GNP に対する援助額の比率を高めるべく努力す る一方で, 土木技術者一人ひとりが自らの技術を切硡瓈 磨しそれを発展途上国へ提供する. 自分の技術が被援助 国を一歩前進させたことに喜びを感し，また発展に寄与 できたことを糧として新たな研鑚を積む.これこそが土 木屋に課せられた技術協力の真の姿である.

\section{2. 日本の土木技術者の心}

発展途上国に適用される日本の土木技術は，紛れもな く日本人に培われ日本の土壌に育ったものである. その 過程において, 大陸加ら伝来した技法や近世から近代一 の変革期に導入された西欧の技術を吸収したことは事実 であるが，今日海外へ移転されている日本の土木技術 は, この近代 100 年の間に日本独自の体系を完成させた ものである. 


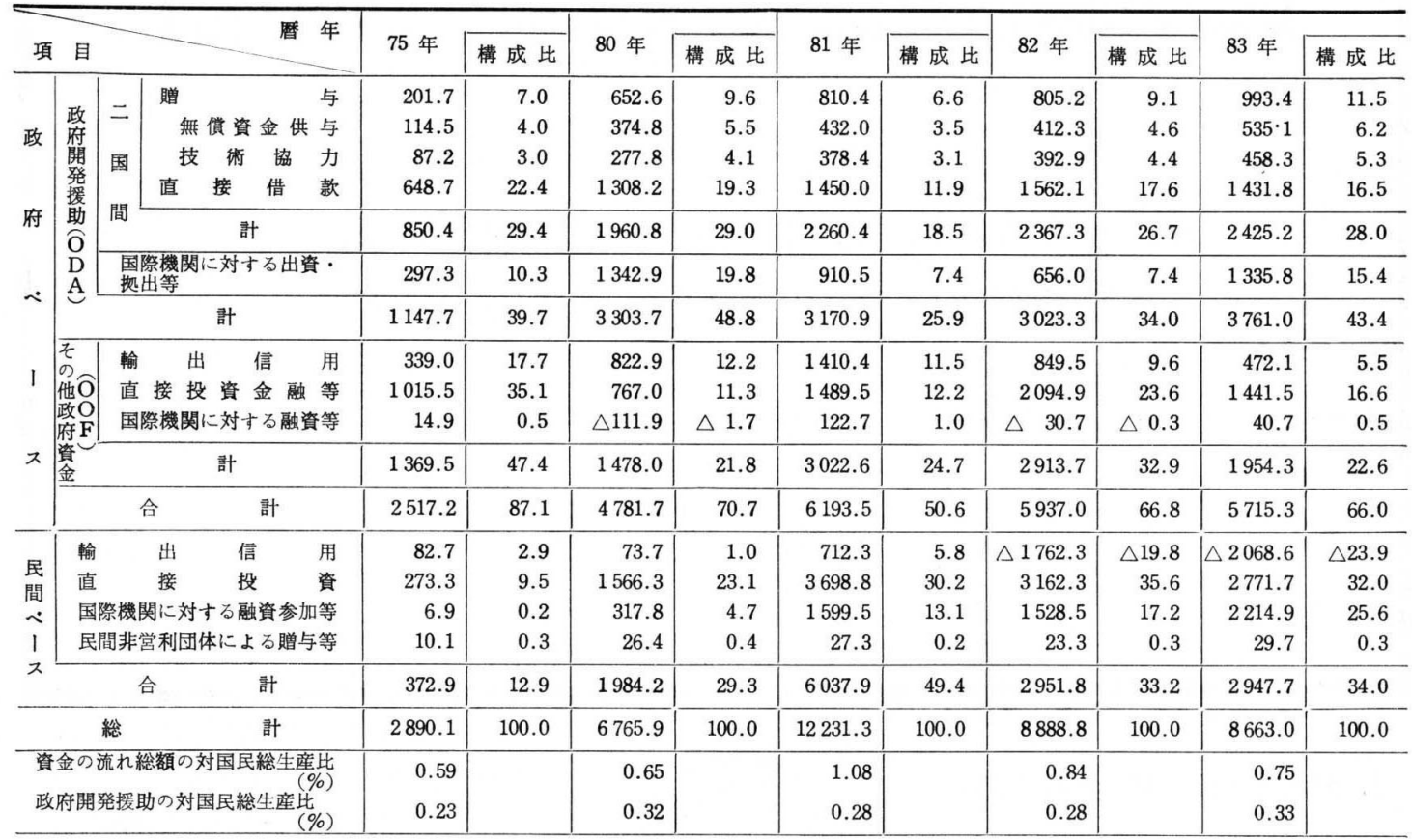

私は，具体的な個々の技術の特異性よりも，技術を開 発しこれを活用している日本の土木技術者の技術に対す る信念, 理念といった部分に, 欧米諸国とは大いなる相 違が存在していると考えている.

明治, 大正そして昭和の前半と, 日本の土木は内務省 や鉄道省を中心に発展してきた. この系譜は戦後におい ても引き継がれ, 建設省, 運輸省港湾局, 国鉄といら官 公の技術者がその責を果たしている.この歷史の中で育 まれた精神が日本の土木技術の根底に流れ, 日本の土木 技術を特徴づけているのである. 日本の土木技術者がイ ンフラストラクチャーを企画し立案する場合，そこでは

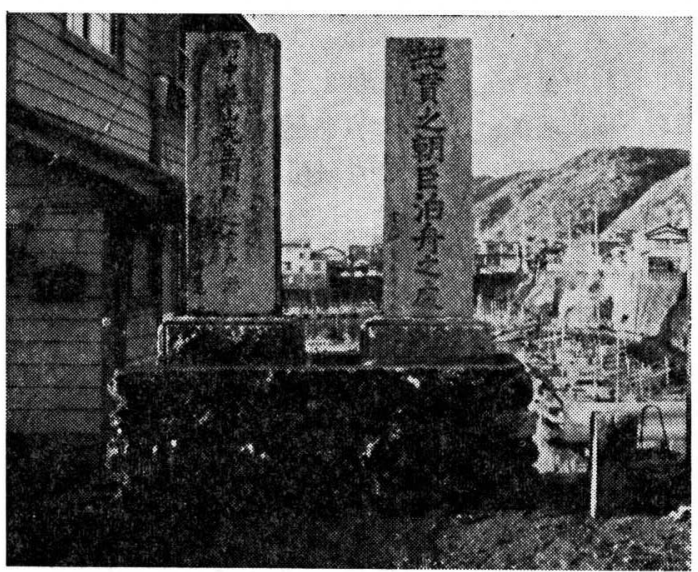

高知県室津港

（野中兼山が 1677 年 1678 年に修築）

写真-1 日本の土木技術 (1)

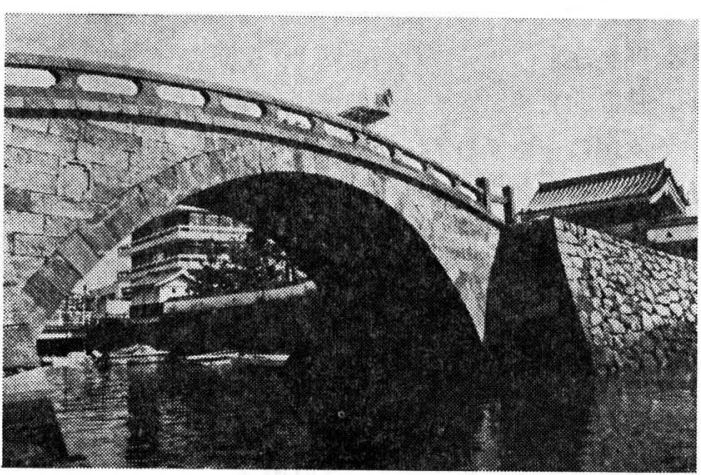

長崎県平戸

(平戸城の城門への橋で 1702 年に完成)

写真一2 日本の土木技術 (2)

個を目的とするあらゆる構想が棄却される．日本全体あ るいは地城を発展させるためには何が必要か，唯一この 観点から計画を策定し事業を推進してゆく．官公を基軸 とした技術の発展には, 奉仕の喜び, 公僕の精神, 犠牲 の心といった国や地域の"礎 となることの誇りが本来的 に内包されているのである.この一見束縛され不自由な 環境とも思える条件下で，日本の土木技術者は創造力を 発揮し独自性を加味しつつ社会の要請に応えてきたとい える. 現在の欧米先進諸国はもとより日本国内において も，例えば建築，機械，造船などの分野を見れば，この 点は容易に理解できよう．経済原則を第一に，弱肉強食 の競争原理に従って技術を蓄積してきたこれらの分野と はその系譜を異にしているといってよい. 
ここで思い出されるのは，新潟県の大河津分水の補修 工事 (同分水は大正 11 年に信瀑川の放水路として完成したか，昭和 2 年 洗掘によって自在嚗が破壞された) の竣功記念碑に刻まれた言葉 である. 昭和 6 年, 当時の内務省新潟土木出張所長であ った青山 士氏の手になる,「万象二天意习覚ル者八幸ナ リ」が正面,「人類ノ為入国ノ為入」が碑の裹側に, そ れぞれエスペラント語訳と並んで銘記されている. 厳肃 な自然の 理”に従って公に奉ぜんとする心情が渗む名文 である.この碑文に, 日本の土木屋の心意気がきわめて 端的に表わされている，見方によっては，「武士は喰わ ねど高楊枝」と一脈通ずる面が感じられる.これがその まま現代に通用するか否かは議論の分かれるところであ ろら. 近年の経済, 社会環境の変化に対応し, 土木の技 術についても他の分野と同様, 企業意識を取り入れて進 歩, 向上を図ることが必要となったが, 国家や地域の発 展に自らを奉ずるという精神は, 日本の土木屋のレーゾ ン・デートルとして不変であると考えている．またこの 理念は, 発展途上国に対する技術の移転に当たっても, 十分生かし得るものと思ら.

\section{3. 港湾の技術移転}

\section{（1） 日本の港湾のエンジニアリンク}

世界の土木部門はその近代化が緒についた時以来, プ ロジェクトの発意者であるプロモーター,プロジェクト・ ライフを通じてエンジニアリングを担当するコンサルタ ント，そしてプロジェクトの実施を請負らコントラクタ 一の三者が独立, 分権して発達してきた. イギリスなど を例にとれば，発注主でもあるプロモーターが建築事業 の場合主として民間であり, 道路, 鉄道, 河川などは政 府によるといら形態であった。これらのプロモーター が, プロジェクトの実施に当たり, エンジニアリングに ついてはコンサルタントに発注し, また施工については コントラクターに請負わせる. 契約に際しては複数民間 企業の入札方式によるというシステムである.この欧米 のシステムが現在世界の主流となっており，長い間この ような欧米流の考え方に慣らされてきた発展途上国も同 様の発想に立っている. 国際金融機関, 例えば世銀 (国 際復興開発銀行: IBRD), アジ銀 (アシア開発銀行：ADB）なども またこのシステムを基本に設立, 運営されている.

日本では，短時日のらちに欧米の技術水準に到達しょ らとしたこともあり，技術者の育成を含め一貫して国が 主導的な役割を演じてきたことは既に述べたところであ る. 帝国大学を中心に土木技術者を養成し, 内務省への 採用後は国の行政官として権限を与え, 活動の場を提供 してきたのである. 加えて, 内務省は直轄直営方式によ
り公共事業としてインフラストラクチャーの整備を進め た.このことは, 日本については当初よりプロモータ 一, コンサルタント，コントラクターの区分が存在しな いことを意味し，国自らが資金を負担し，計画・設計 し，そして施工してきたといらことである.これが，欧 米とは異なる今日の日本型システム形成の端緒と考えら れる. 港湾もまた，土木の一部門として全く同様の枠組 の中にあったことはいらまでもない.

戦後の混乱期を克服して日本が経済発展の道を着実に 歩み始めたころ, その先導役として港湾の事業量も急激 に拡大し, これに対処するため先ずコントラクターの育 成が求められるところとなった. 官が行っていた施工の 部門を民間へ移譲していったわけである. その後いわゆ る高度成長期に入り, エンジニアリングの業務のうち施 設の設計などのハードな業務を行えるコンサルタントが 誕生したが，今日に至るまでソフトを含む港湾計画の企 画立案については, 国および地方公共団体などの官の領 域に依然として委衫られている.

近年に至って, 官とこれら民間コンサルタントとの間 で人材の交流が活発化し, 官側に蓄積されている港湾技 術のノウハウ, 特にソフトの部門が, 漸次民の側に移り つつある.また, 発展途上国に対する港湾技術の移転 を, 他の先進諸国に伍して進めてゆくためには, 今後民 間コンサルタントの発展が強く求められるところであ る. しかし少なくとも当分の間は, エンジニアリング, 特にその計画等のソフト部門において, 技術協力の相当 部分が官の主導の下で行われざるを得ない.とはいえ, 長期的にはコンサルタントの質が向上し, 彼等を通じて 日本の港湾技術の権威, 信用度が高められる方向に進む ものと期待している.

\section{（2） 日本の港湾開発の理念}

港湾の場が海陸交通の結節点であることは論を俟たな い.この観点からのみ俯瞰すれば,港湾は輸送施設の集合 体であるとする矮小な概念整理が可能かも知れない. 現 に欧米の一部で, そしてその影響下にあった発展途上国 の中には港湾開発のプロジェクトを港湾施設の建設工事 と同義と考えている政策担当者を見受けることがある.

日本に括ける港湾の学術的な定義は,「港湾法解説」 (昭和 25 年 : 巻幡静彦),「港湾行政」(昭和 30 年 : 住田正二) など の文献を参照いただくこととし，欧米の港湾との相違に ついて実態的に触れてみたい.

国土が狭小であることに加え可住地となる平地が少な く，またエネルギー資源なども乏しいわが国にとって， 臨海部を開発し活用することは国の発展のために不可欠 であった． 戦後, 日本が正に発展途上国であった時, 産 業を振興し貿易を拡大するための唯一の資源, それが海 
を抱えた臨海部がもつポテンシャルであったのである. 一方で都市への人口集中が進み, 都市形成のための場と しても臨海部の空間が求められた．日本の港湾はこの臨 海部空間のインフラストラクチャーであり，というより はむしろ臨海部空間そのものと観念すべきものである. これが日本の港湾を特徽ゔけている基本的概念である.

国もまた，この重要な港湾の整備のため行政上種々の 施策を講じた. 繰り返し述べたように, ここでも官公が 主導的立場に立ってプロジェクトが推進されたわけであ り, 今日までその流れは続いている. 東京湾内諸港の海 面埋立による産業空間, 都市空間の確保, 鹿島港の開発 による首都圈の機能の均衡化, 大阪港, 神戸港の人工島 プロジェクトによる空間の創造など，いずれも典型的な 日本型の港湾開発の理念に基づいた成果である.

日本の港湾のもう一つの特徴としてその地域性, 公共 性を挙げなければならない。

日本の港湾が臨海部空間そのものであることに起因し て, そこで営まれる活動には, 単に物流, 人流に倸る経 済活動のみならず広範な経済, 社会活動が含まれること となる. 例えば, 港湾施設を利用した荷役, 輸送, 保管 といった物流活動はもとより, 工場による加工, 生産活 動, 地域住民の日常生活, レクリェーション活動などで ある.これらはいずれも地域の活動そのものであり，こ

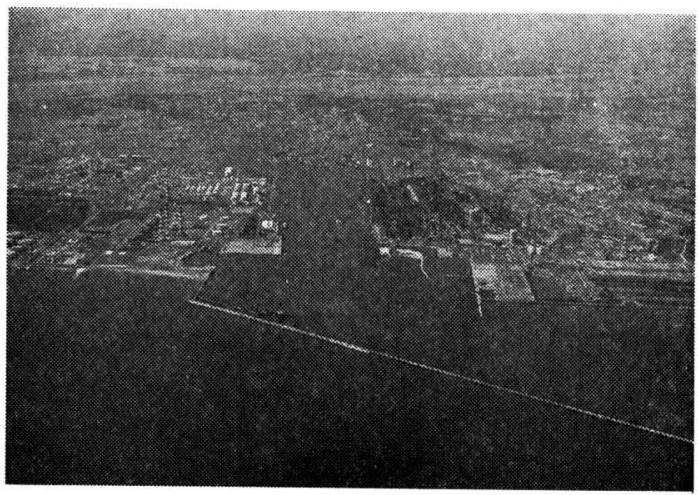

写真一3 鹿 島 港

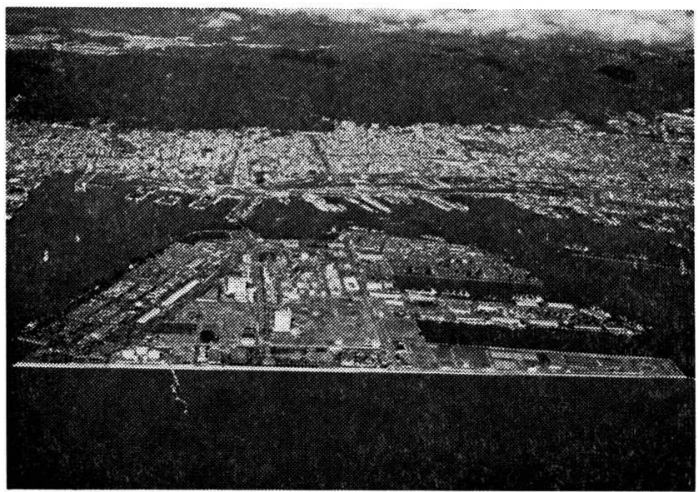

写真-4 ポートアイランド
のため，港湾を管理するということは，地城の行政を行 うことと同等であるともいえる.

日本の港湾を管理している港湾管理者は，このような 背景もあって, そのすべてが地方公共団体（都道府県，市町 村）またはそれらにより構成される組織となっている. 欧米の港湾が，ポートオーソリティといわれる港湾管理 のための独立した組織により経営されているのと比べ, このことは際立った相違点である. 日本の港湾管理者 が，地域の発展，地域住民の生活向上を目的とした港湾 整備, 港湾運営を意図しているのに対し, 欧米のポート オーソリティが，むしろ収益性の良否といら私企業経営 の観点から港湾の管理を行っているといら差は，ここに 理由がある. 日本の場合, 港湾の開発, 整備に国, 地方 公共団体が敗政的援助措置を講じているのもまた，港湾 の公共性を重視しているからにほかならない.

多くの発展途上国で，特に海岸線を多く持ち，あるい は島嶋の多い日本に似た東南アジア, 中南米あるいは中 国で，国や地域の経済発展，国民の生活水準の向上のた め港湾開発に努力しているが，私は日本の港湾開発に対 する考え方を彼等が理解し，そしてそれを適用すること がその国の発展に連なる一つの方策ではないかと思って いる.もしそれが適応されるならば，日本のノウ八ウを 彼等に移転するのがわれわれの役割と考えるのである.

\section{（3）技術移転の姿}

発展途上国に対して技術の移転を図る場合に何よりも 重要なことは, 相手国の立場に立ち, 相手国の身になっ て考えるという姿勢である. 今日，様々な意味において 日本は「持てる国」と呼ばれている，一方，発展途上国 は「持たざる国」である.この関係が時として技術協力 の場に顔を出し, 円滑な技術の移転の障害となる例も多 い. 一般に発展途上国は民族独立の意識が強く, 援助, 被援助の立場についても全く対等であるとの認識を持っ ている.このため，「教えてやる」式の技術協力は相手 国のプライドを傷つけるのみならず，両国間に築かれた 貴重なパイプを失うことにもなりかねない，

技術協力といらのは, 結局は相手国の自助努力を補 助，支援してやることであると思う．先進国側の技術の 強要であってはならないし, また発展途上国側の努力な しには協力の効果も期待できない，例えば港湾の技術は その総合性に特徵があるが,これも長年月にわたる基本 的な技術の積み重ねにより体系化されたものである．技 術の移転に当たっては, 発展途上国側の技術の進歩と調 和を図りながらこれを進める心構えが必要であろう。

技術移転は，通常ある対象に対する技術協力からス夕 一トする．例えば港湾の開発プロジェクトに係るフィー ジビリティ調查といったものからである．このような調 
査を通じて発展途上国側の技術者, いわゆるカウンター パートに日本の技術が移転されてゅく。これが最も基本 的な形態であり，マンツーマンのパイプが重要な役割を 演じている.これが発展して, 研修やセミナーによる技 術者の養成, 専門家を派遣してのより高度な技術移転, あるいは実験施設の建設，コンピューター等の資機材の 提供とこれらを活用するための技術指導へと進む.さら に, 移転される技術が一般化し, 発展途上国に扮いて政 策判断をするための手段に供せられるほどにレベルアッ プすれば，この技術移転は成功したものと評価してよ い. 港湾では, 産業の立地論, 企業誘致の方法論, 都市 計画の技術などインフラストラクチャーとしての港湾に 係る種々の複合技術が移転の対象となっている．

発展途上国への技術移転にはコントラクターがまた重 要な責務を負っている. 現に施工されつつある施設を教 材として利用できることに加え，現地に長期間滞在して 技術移転を行えるといらことは，人と人とのつながりに 依存する技術協力に打いてはきわめて有利である. 企業 として保有する技術を軽々に開放できないことは理解で きるが，相手国の自助努力に対して少しでも貢献しよう とする姿勢が必要と思われる. これが新しい事業の確保 に結びついた例は決して少なくはないのである.

\section{OCDI の機能}

参考までに私の専門の分野である港湾における技術協 力の具体的な実践例として, (財) 国際臨海開発研究セン ター (The Overseas Costal Area Development Institute of Japan : OCDI）の実態について述べることとしたい.

OCDI は, 昭和 51 年 7 月に 運輸省を主務官庁とする 財団組織の公益法人として設立された．臨海部の開発に 係る技術を発展途上国へ移転することなど，OCDI の設 立趣旨に賛同いただいた民間企業の出捐金などを基本財 産としているが，その活動は公益的，中立的であること に徹したものとなっている.

日本の政府が関与する港湾プロジェクトの調 査は, OCDI が設立される以前は国 (運輸省港涾局) 自らが実施し ていた. すなわち，行政事務の一環として国の職員が事 前調查, フィージビリティ調査, 場合によってはアプレ イザル (評価) 調查までを行っていたのである.しかしな がら, 発展途上国側の要請が強まりプロジェクトの規 模, 件数が増加するにつれ，この方式では十分に技術協 力を遂行してゅくことが難しくなり，さらに一方では， 民間における夫々の分野での技術が進展し，そのノウ八 ウの活用が期待されていた．このような状況下で，官民 の保有する臨海部開発の技術を総合的に運用することが でき，かつ国に代って技術協力を実施することができる

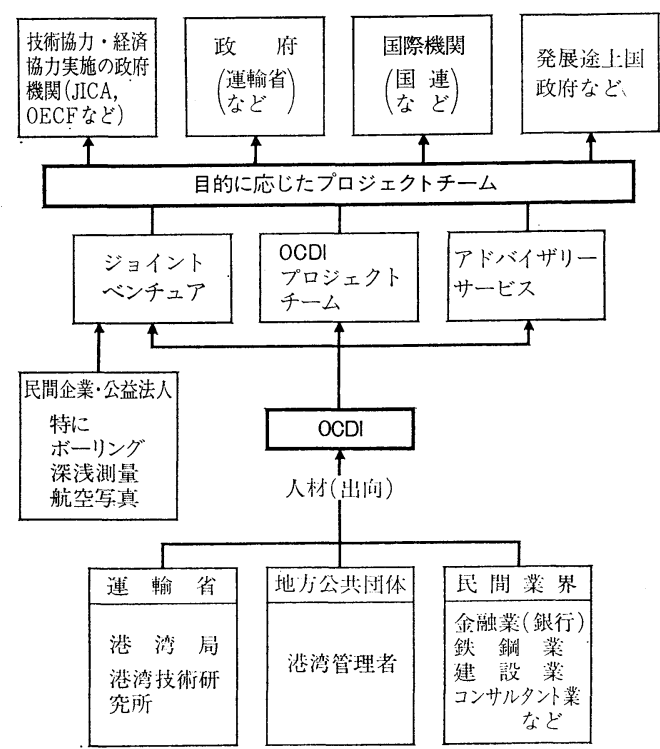

図一1 OCDI の仕組み

民間の組織として OCDI が設立されたわけである.

OCDI はその誕生以来，相手の立場にたって考えるこ とを基本的な精神とし三つの運営方針に沿って活動を展 開してきた。 それらは，(1)海外の仕事以外は受託しな い，(2)給与は OCDI が負担する，(3)民間の企業が行え る業務には進出しない，というものである.

コンサルタントの経営は難しく，特に海外との競争は 激しい。一般には国内に打汀業務によって経営の基盤 の安定化を図り，その上で海外の仕事を実施する．発展 途上国一の技術協力などで収益性の悪い仕事などではど うしても国内業務と併行してやらざるを得ないのが実情 である. OCDI の方針の11はこの甘えを断ち，専心相手 国の立場に立った技術協力に努めるため，自らを律した ものである.

(2)は OCDI の出向制度に関連した社是といえる.官 民の協調の下で日本の港湾技術を発展途上国側へ提供す るため, OCDI 職員の大半が国，地方公共団体および民 間各社からの出向者で構成されている. 公益法人といえ ぞも安定的な経営が必要であり，この観点からすれば出 向者の給与を親機関に依存する考え方も取り得る。しか しながら，親方日の丸的な仕事を忌避するためには，自 らの給与は自ら稼ぐという姿勢が重要であり, OCDI 創 設以来この方針が貫かれている.

(3)は，民間のコンサルタントの経営を圧迫しないこと を念頭に置き，民間の技術力を伸展してもらうための方 針である．多くの努力を通じて，少しずっではあるが， 官のノウハウが民間へ移転されつつある．港湾の分野に おいても国際競争に耐えられる力を持つ民間コンサルタ ントが育ちつつあると期待される。このように民間のコ 
ンサルタントが実施可能な分野については，公益法人で ある OCDI は中立的な立場をとることとし，彼等の自 主性を尊重することを明確にしたものである。

OCDI は創設後来年で 10 周年を迎える.心が通じ合 えるまでに関係の深まった発展途上の国々は，今やアジ ア，アフリカ，中南米など世界の全域に及んでいる．港 湾のプロジェクトに関しては，これらの諸国から OCDI の技術に大きな信頼も寄せられている.

今後は, 発展途上国の成長に伴いハードな技術からン フトな技術へとその要請が移行してゆくものと予想され る. 国が保有するソフトの技術を民間的組織形態の中で 活用するため設立された OCDI であるから，これから も外務省, JICA (国際協力事業団) とも連携を深めながら発 展途上国側の期待に応えてゆかなければならないだろ 5 .

技術協力の成果について色々な角度からの見方があ る. 金額の高, 事業化の量等にであるが，その国に及ぼ す実質的な貢献が最も大切である.色々な考え方があろ らが OCDI の持つ性格は参考の一つとして頂きたい.

\section{5. 新土木技術の開発}

技術は日進月歩する．官側に蓄積されていた土木技術 が民間側へ，日本の高度な技術が発展途上国へと移転さ れ，相対的には技術水準が平滑化の方向一進む. かつて のわが国がそうであったように, 発展途上国側の技術は いずれ先進諸国側の現在のレベルに到達するであろら し，それを願う者である。
高度経済成長期までは国内での土木事業が量的に恵ま れていたこともあり, 技術の開発の場, そのための題 材，検証の機会などを見い出すことが容易であった．こ こ数年，国の財政が逼迫し公共事業が抑制され続け，ま た民間の設備投資も縮小傾向となったことから，日本の 土木技術者にとって新しい技術に挑戦することが困難な 時代を迎えたといえよう．このまま推移すれば，日本か ら発展途上国へ移転する技術が枯渇してしまうと懸念す る向きもある.本当にそうであろうか。

日本の自然は世界的に見れば䉷しい, 台風, 地震, 軟 弱地盤など，狭小な国土を最大限に活用するためこれら の自然の脅威と闘い，時には妥協してきたというのが日 本の土木技術の歴史である. 自然的, 経済的, 社会的制 約の中で国の基盤づくりを担った日本の技術は，あらゆ る面で制約が強まるであろら将来において，自らの研鑚 に急りがなければ, 発展途上国の要請に応え得るものと 思う. 科学の進歩に惑わされ, 自然の力に打ち勝てたが 如き過信が生じた時日本のリーダーシップは失われる。 今日日本の土木技術者がその解決に悩み，苦しんでいる 課題が，わが国が近代国家の仲間入りをして以来のもの であるといらことは，当の土木技術者自身が最も熟知し ていることである。

技術を移転される相手国の立場に立って考え，真に相 手国の発展のために行おらとする日本型の技術協力, こ の精神こそが，技術の移転を進める上で何よりも重要で あると思っている.

（1985.7.5 • 受付）

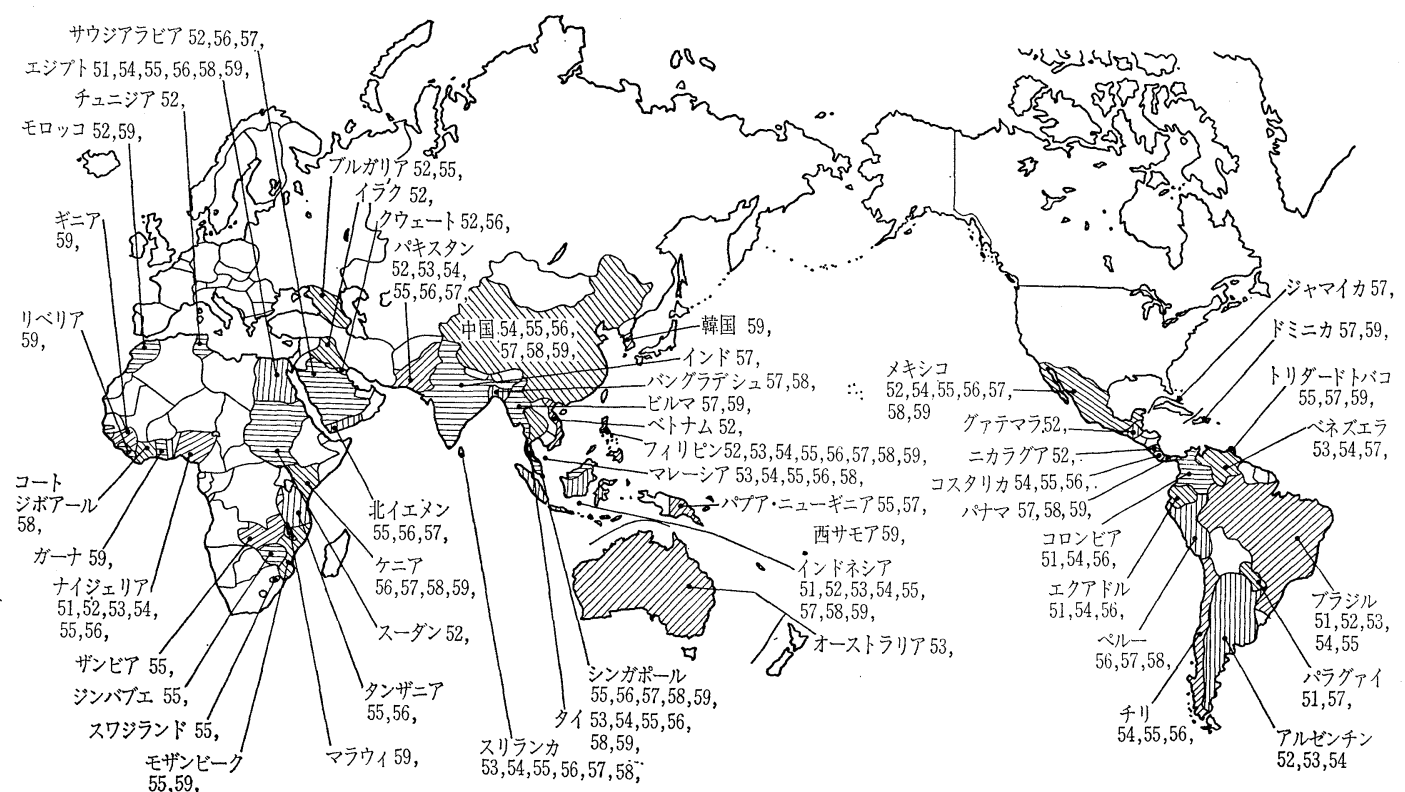

図一2 OCDI が係った国々 